\title{
Paleoenvironmental change at the Danian-Selandian transition in Tunisia: Foraminifera, organic-walled dinoflagellate cyst and calcareous nannofossil records
}

\author{
Elisa Guasti ${ }^{\mathrm{a}, *}$, Robert P. Speijer ${ }^{\mathrm{b}}$, Henk Brinkhuis ${ }^{\mathrm{c}}$, Jan Smit ${ }^{\mathrm{d}}$, Etienne Steurbaut ${ }^{\mathrm{b}, \mathrm{e}}$ \\ a Department of Geosciences (FB 5), Bremen University, P.O. Box 330440, 28334 Bremen, Germany \\ ${ }^{\mathrm{b}}$ Department of Geography and Geology, K.U.Leuven, Celestijnenlaan 200E, 3001 Leuven, Belgium \\ ${ }^{\mathrm{c}}$ Laboratory of Palaeobotany and Palynology, Utrecht University, Budapestlaan 4, 3584 CD Utrecht, The Netherlands \\ ${ }^{\mathrm{d}}$ Department of Sedimentology, Faculty of Earth and Life Sciences Vrije Universiteit, de Boelelaan 1085 1081HV Amsterdam, The Netherlands \\ ${ }^{\mathrm{e}}$ Royal Belgian Institute of Natural Sciences, Vautierstraat 29, 1000 Brussels, Belgium
}

Received 8 July 2005; received in revised form 2 February 2006; accepted 20 February 2006

\begin{abstract}
In the present study, we document paleoenvironmental change across the Danian-Selandian transition (planktic foraminiferal interval P2-P3b; calcareous nannofossil Zone NP4, Subzones NTp6-NTp8A; 61-59Ma) in NW Tunisia. Diversifications of Paleogene planktic foraminifera with the evolution of the muricate and photosymbiotic lineages Morozovella, Acarinina and Igorina and of the biostratigraphically important nannofossils genus Fasciculithus are recorded within this interval. The present study aims to understand early Paleogene environmental changes in the southern Tethys, by analyzing the evolution of surfacewater and-to a lesser extent-seafloor conditions. Three localities were investigated: Ain Settara, Elles and El Kef, all representing outer neritic deposition in the same basin, the Tunisian Trough. Paleoenvironmental changes are explored by combining planktic foraminiferal, organic dinocyst and calcareous nannofossils assemblages and several proxy parameters (planktic/benthic ratio, numbers of planktic foraminifera per gram, peridinioid/gonyaulacoid ratio; terrestrial/marine palynomorph ratio). In addition, also some geochemical parameters (calcite content and stable isotopes) are examined. Our records indicate that the environment evolved from an initially oligotrophic, open marine, deep outer neritic setting in P2-P3a towards a shallower and nutrient-rich setting from the base of Subzone P3b. This change is seen in the foraminiferal assemblages, with the substitution of Praemurica by Morozovella among the planktic foraminifera and an upward decrease in deeper benthic taxa. Also the organic-dinocyst assemblages show a peak of peridinioid cysts (Cerodinium and Lejeunecysta). Associated to these dinocyst assemblages, the lowest occurrence of Apectodinium is recorded, which seem to have evolved in this region, possibly in response to enhanced nutrient levels on the shelf. Additionally, a distinct change in calcareous nannofossil assemblages is also described, marked by the lowest appearance of Chiasmolithus edentulus, the lowest consistent occurrence of Fasciculithus and a slight increase in near-shore taxa (essentially Pontosphaera).

This project provides an accurate understanding of paleoenvironmental change across the Danian-Selandian transition in Tunisia. Especially, integrating different proxies demonstrates a paleobathymetric shallowing from the Danian to the Selandian, associated to increase surface paleoproductivity. Furthermore, the results are compared with those from other localities along the
\end{abstract}

\footnotetext{
* Corresponding author. New address: Fugro Robertson Limited, stratigraphy group, Llandudno LL30 1SA, North Wales, UK. Tel.: +44 1492 581811; fax: +44 1492583416 .

E-mail addresses: elisa.guasti@fugro-robertson.com (E. Guasti), $\equiv$.speijer@geo.kuleuven.be (R.P. Speijer), H.Brinkhuis@bio.uu.nl (H. Brinkhuis), smit@geo.vu.nl (J. Smit), etienne.steurbaut@naturalsterres.be (E. Steurbaut).
} 